\title{
Effects of methanolic plant extracts on cell proliferation and HIF activity under hypoxic condition in vitro
}

\author{
Pheik-Sheen Cheow ${ }^{a^{*}}$, Norazizah Shafee ${ }^{\mathrm{a},{ }^{*}}$, Sien-Yei Liew ${ }^{\mathrm{a}, \mathrm{b}}$, Muhajir Hamid ${ }^{\mathrm{a}}$ \\ ${ }^{a}$ Department of Microbiology, Faculty of Biotecbnology and Biomolecular Sciences, Universiti Putra Malaysia, Serdang, Selangor, Malaysia \\ ${ }^{b}$ Department of Biomedical Science, Faculty of Medicine, University of Malaya, Kuala Lumpur, Malaysia
}

Received 9th June 2018 / Accepted 29th November 2018

\begin{abstract}
Low oxygen tension is termed as hypoxia. Hypoxia will lead to transcription of hypoxiainducible factor (HIF) and regulation of downstream gene expression. Underexpression or overexpression of HIF was found to be responsible for various diseases. Proper regulation of this transcriptional factor will aid in treatment of the related diseases. Nowadays, many different approaches are used to modulate HIF, including the usage of naturally-derived plant extracts. Plant extracts are widely accepted compared to other treatments as they are less harmful to the patient and are widely available. In this study, the cytotoxicity of eight different plant extracts under two different gaseous conditions, hypoxic and normoxic, were examined. We also examined the HIF activity shown by the cells under treatment of various concentrations of plant extracts. All eight plants were dried, blended, extracted using methanol, and evaporated to form crude plant extracts. MTT assay was performed by treating the cells with different concentrations of plant extracts and cell viability was determined. Meanwhile, HIF activity of the cells was evaluated by using single luciferase reporter assay. Relative cytotoxicity shown by the cells was different for each plant extract under the various concentration. Pereskia bleo, Orthosiphon aristatus, and Clinacanthus nutans showed high cell viability, $80 \%$ of cell viability, within the range of concentration tested. In contrast, Gynura procumbens, Hydrocotyle sibthorpiodies, Pereskia grandifolia, Strobilanthes cripus, and Melastoma malabathricum showed low cell viability. Most of the cells showed activation of HIF activity when treated with different concentrations of the plant extracts. When cells were treated with high concentrations of plant extracts, inhibition of HIF activity were seen and was correlated with low cell viability after treatment. The most notable part of the study was that more than 100\% HIF activation was observed for Clinacanthus nutans. However, the cell viability remained high. This might indicate that Clinacanthus nutans is a promising candidate to activate HIF at a transcriptional level with minimal cytotoxicity.
\end{abstract}

Keywords: HIF activation, hypoxia, plant extracts

\section{INTRODUCTION}

Oxygen is a basic survival need for living organisms. Oxygen deprivation in cells or tissues is termed as hypoxia (Harris, 2002). Cellular responses during hypoxia are executed by a transcription factor known as hypoxia-inducible factor (HIF). HIF is a dimeric transcriptional factor that consists of an oxygen dependent HIF$\alpha$, and constitutively expressed HIF- $\beta$ isomers (Stroka et al., 2001). The aftermath of HIF expression can be deleterious or protective

\footnotetext{
* Author for correspondence: Pheik-Sheen Cheow, Norazizah Shafee. Department of Microbiology, Faculty of Biotechnology and Biomolecular Sciences, Universiti Putra Malaysia, Serdang, Selangor, Malaysia. Email cheowpheiksheen@yahoo.com / nshafee@gmail.com
} 
towards our body. HIF was claimed to be responsible to various diseases such as human cancers and chronic kidney disease (Mabjeesh and Amir, 2007; Gunaratnam, 2009). Upregulation of HIF was found to activate the transcription of downstream genes that intensify disease progression. However, appropriate suppression of HIF can therapeutically target these HIFrelated diseases. On the other hand, HIF activation is reputed to be useful in treating ischemia and aid in wound healing for diabetic patients as upregulation of HIF stimulates angiogenesis (Ziello et al., 2007; Mace et al., 2007). Angiogenesis is said to be able to deliver more oxygen supply to specific regions by promoting formation of new blood vessels from pre-existing vasculates (Birbrair et al., 2015).

Identification of new chemical entities (NCEs) is essential for the development of new drugs. In recent years, plant extracts have become new targets for drug discovery and a source of NCEs, which are isolated from plant extracts (Katiyar et al., 2012). Drug discovery based on natural products mainly target these predominant therapeutic areas: anticancer activity, immunosuppression, antimicrobial activity, and cardiovascular health (Pan et al., 2013). Alternative complimentary medicine, especially naturally-derived plant extracts, turn out to be a preferable choice compared to current treatment modalities due to better tolerance and acceptance in patients (Paul et al., 2013). In addition, plant extracts are naturally available, thus making them more accessible.

There are many diseases related to HIF. Plant extracts might be the key to developing more drugs to combat HIF-related diseases. The main objective of this study is to examine the relationship between cell cytotoxicity of the medical plant extracts and the corresponding HIF activity level. Therefore, we investigated the concentration-dependent effect of the relevant plant derived extracts towards HIF activity using an established HIF luminescent cell-based assay system (Shafee et al., 2015). The plant extracts were used to treat Saos-2 cells that were stably transfected with hypoxia-driven firefly luciferase plasmids containing four copies of the erythropoietin (EPO) hypoxia response elements (HRE; Liew et al., 2015).

\section{MATERIALS AND METHODS}

Cell culture and culture condition. Cultured Saos-2 human osteosarcoma cells and C3, the genetically-modified Saos-2 cells (MY Patent filing no. PI2012003492, PCT no. WO2014021705 A1, U.S. filing no. 14/415,064, India filing no. 205/DELNP/2015, Europe filing no. 13713255.1 and China filing no. 2015021200444780) which stably expressed firefly luciferase under the control of four copies of the HRE of the EPO gene upon hypoxia induction were used in the study. The low oxygen environment at $0.5 \% \mathrm{O} 2$ was created by culturing the cells at $37^{\circ} \mathrm{C}$ in the hypoxic incubator (Galaxy 48R, New Brunswick, USA). The incubator was set to $94.5 \% \mathrm{~N} 2,5 \% \mathrm{CO} 2$ and $0.5 \% \mathrm{O} 2$.

Preparation of plant extracts, cell culture treatment condition and cell proliferation assay. Eight types of medicinal plants were evaluated in this study. They are Gynura procumbens, Hydrocotyle sibthorpiodies, Pereskia bleo, Pereskia grandifolia, Orthosiphon aristatus, Clinacanthus nutans, Strobilanthes cripus and Melastoma malabathricum. The plants were identified by the botany taxonomist from Institute of Bioscience (IBS), Universiti Putra Malaysia (UPM). Leaves of the tested plants were washed with distilled water, dried and subjected to methanolic extraction as described in Liew et al., 2012. Before treatment, the plant extracts were dissolved in serum-free media with a final DMSO concentration of less than $0.5 \%(\mathrm{v} / \mathrm{v})$. Then, the mixtures were centrifuged at $1000 \mathrm{x} g$ and filtered through 0.22 $\mathrm{mM}$ filters (Sartorius, USA). For plant extracts treatment, cells were seeded at $1.5 \times 10^{4}$ cells/well in a 96-well plate. After the cells were treated with selected concentrations of plant extracts, the cells were incubated in hypoxic conditions. After $24 \mathrm{~h}$ of incubation, a viability MTT assay (Vijayakumar \& Ganesan, 2012) was performed to measure the cell viability.

Single luciferase reporter assay. In order to ensure the HIF regulatory effect of the selected medicinal plants, C3 cells, the geneticallymodified Saos-2 cells as mentioned above was utilized to measure the HIF activity. C3 cells were seeded at $1.5 \times 10^{4}$ cells/well in DMEM 
supplemented with 10\% FBS in 96-well plate for $24 \mathrm{~h}$. After overnight incubation, cells were treated with selected plant extracts in a dosedependent manner and followed exposure to hypoxia $(0.5 \%$ O2) for another $24 \mathrm{~h}$. Bright$\mathrm{Glo}^{\text {TM }}$ single luciferase reporter assay was conducted as described according to the manufacturer's instruction to evaluate firefly luciferase expression which was an indication of the level of HIF activity of C3. HIF activity was calculated by using the formula below:

$$
\text { HIF activity }=\frac{\text { HIF activity of the desired concentration }- \text { HIF activity of control }}{\text { HIF activity of control }} \times 100 \%
$$

Positive value of HIF activity indicates HIF inhibition whereas negative value indicates HIF activation.

Statistical analysis. The Student t-test was used to analyse the experimental data in this study. Results were expressed as mean \pm SEM by using Graph Pad Prism 5.

\section{RESULTS AND DISCUSSION}

Cell viability under hypoxia. In this study, we intended to study the concentration-dependent effect of the above mentioned methanolic plant extracts towards cell viability and HIF activity of Saos-2 cells under hypoxia. In order to determine cell viability and HIF activity, C3, the stable cellbased HIF assay system was employed. Cisplatin (Duyndam et al., 2007; Figure 1A) and bortezomib (Befani et al., 2012; Figure 1B) were included as positive controls. During treatment under hypoxic condition, cell viability decreases upon increasing concentrations of cisplatin, but bortezomib does not show any cytotoxic effect.

For G. procumbens and H. sibthorpiodies, they displayed different cytotoxicity levels when treated with different concentrations under hypoxia. However, both plant extracts demonstrated a high induction in cell viability when cells were treated with the first two concentrations used, 500 and $750 \mu \mathrm{g} / \mathrm{ml}$ for $G$. procumbens, and 125 and $250 \mu \mathrm{g} / \mathrm{ml}$ for $H$. sibthorpiodies (Figures 1C and 1D). A decrease in cell viability for both methanolic plant extracts was observed for treatments beyond these two concentrations. Similar killing curve patterns were obtained for cells treated under normoxic conditions (Supplementary Figure 1). The increase in cell viability was supported by few researchers who showed that both plant extracts assisted in the wound healing process (Somboonwong et al., 2012, Zahra et al., 2011). Our findings in cell proliferation under either hypoxia or normoxia may contribute to an understanding of the mechanisms underlying the wound healing process.

$P$. bleo and P. grandifolia are both from the cactus genus. Within the Cactaceae family, these are the only ones with green leaves (Sharif et al., 2013). Even though both of the plants are from the same genus, the extracts exhibited different cytotoxic effects on the cells. P. bleo showed no obvious cytotoxicity, but a gradual increase in cell viability even though C3 was treated with a high concentration under hypoxia (up to $1500 \mu \mathrm{g} / \mathrm{ml}$; Figure 1E). Similar conditions were also observed in the plant extract treated cells that were incubated under normal oxygen levels (Supplementary Figure 1). The findings, done under normoxia, contrasted a study conducted by Tan et al. (2004) that displayed how P. bleo killed almost $90 \%$ of the cells at a very low concentration, $3 \mu \mathrm{g} / \mathrm{ml}$. Under hypoxic conditions, cells treated with concentrations of $P$. grandifolia lower than $50 \mu \mathrm{g} / \mathrm{ml}$ retained almost $100 \%$ cell viability (Figure $1 \mathrm{~F}$ ). Then, a decrease in cell viability was observed when cells were treated with $75 \mu \mathrm{g} / \mathrm{ml}$ of plant extract and remained at the same level when higher concentrations were used. This was dissimilar to what was observed for the P. grandifolia-treated cells when incubated in normoxic condition. High mortality, and less than $50 \%$ cell viability were detected when concentrations higher than 75 $\mu \mathrm{g} / \mathrm{ml}$ of methanolic plant extract were used (Supplementary Figure 1). Results obtained from 
the cells treated with $P$. grandifolia under normoxia were in agreement with a study by Nurestri et al. (2009), in which cytotoxicity was observed towards several cancer cell lines by having IC50 values ranging from 34 to $88 \mu \mathrm{g} / \mathrm{ml}$.

For $O$. aristatus and $C$. nutans, both plants exhibited minimal cytotoxicity towards $\mathrm{C} 3$ under hypoxic conditions (Figures $1 \mathrm{G}$ and $1 \mathrm{H}$ ). Overall, C3 treated with various concentrations under hypoxia showed cell viability of more than $70 \%$. A similar concentration-dependant curve was observed for $C$. nutans treated cells incubated under normal oxygen concentrations, but the opposite was observed for $O$. aristatus. In normoxic condition, there was a drop in cell viability for cells treated with $400 \mu \mathrm{g} / \mathrm{ml}$ of $O$. aristatus plant extract (Supplementary Figure 1). Vijayan et al. (2013) reported that O. aristatus extract had limited cell inhibitory activity, showing high IC50 values for several treated cancer cell lines under normoxia. Several studies reported severe cytotoxicity for methanolic $C$. nutans plant extracts towards different cancer cell lines by providing IC50 values that ranging from $47 \mu \mathrm{g} / \mathrm{ml}$ to $96 \mu \mathrm{g} / \mathrm{ml}$ when the cell was treated under normal oxygen concentrations (Yong et al., 2013; Arullappan et al., 2014). Results from the prior research were in contrast to our current study. One of the possible explanations for the contrast is that different types of cancer cell lines were used.
A

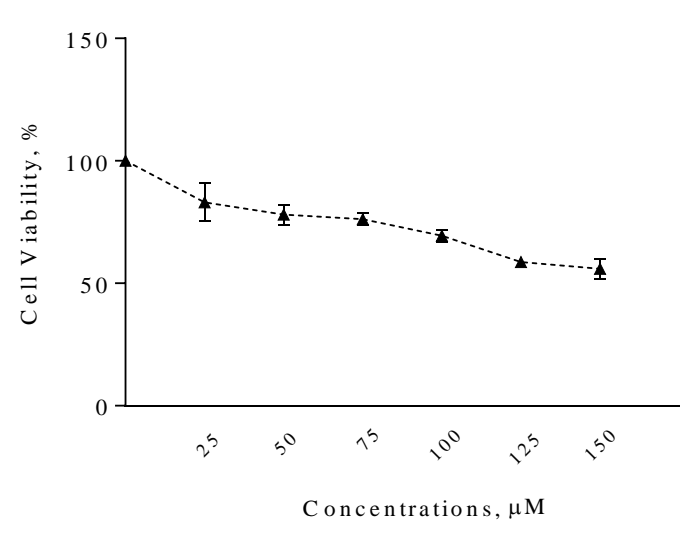

C

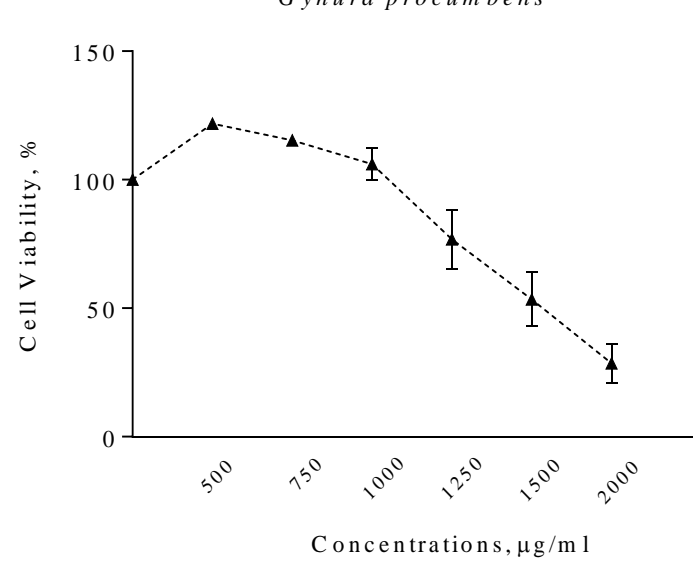

B

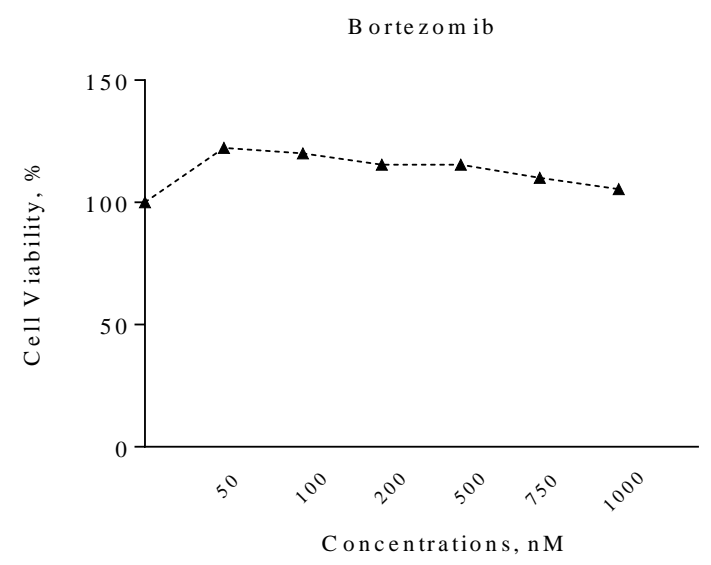

D

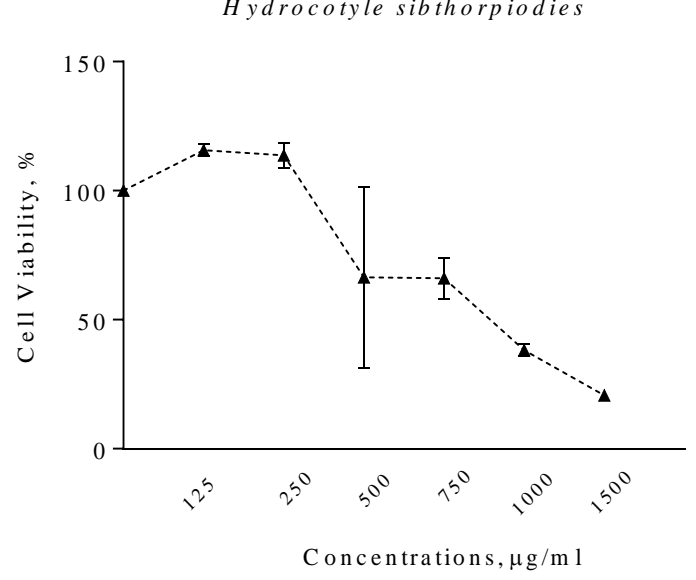

Figure 1. MTT assay for concentration-dependant of positive control drug and each plant extract towards cell viability under hypoxia. (A) Cisplatin (B) Bortezomib (C) Gynura procumbens (D) Hydrocotyle sibthorpiodies. 
E

Pereskia bleo

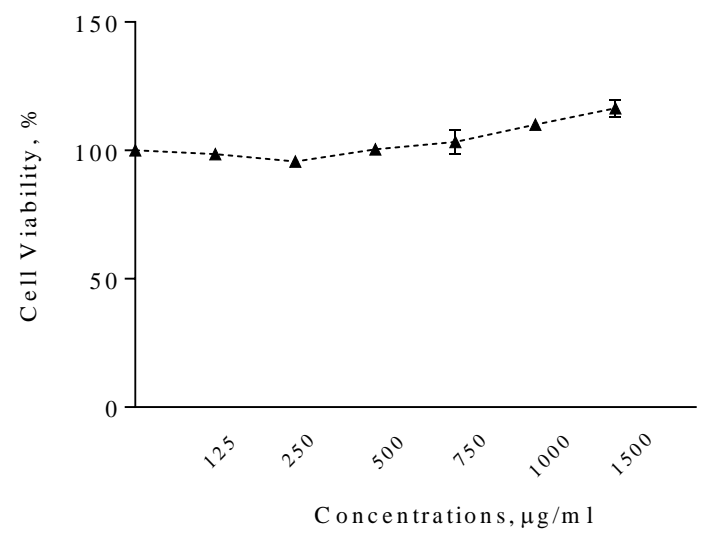

G Orthorsiphon aristatus

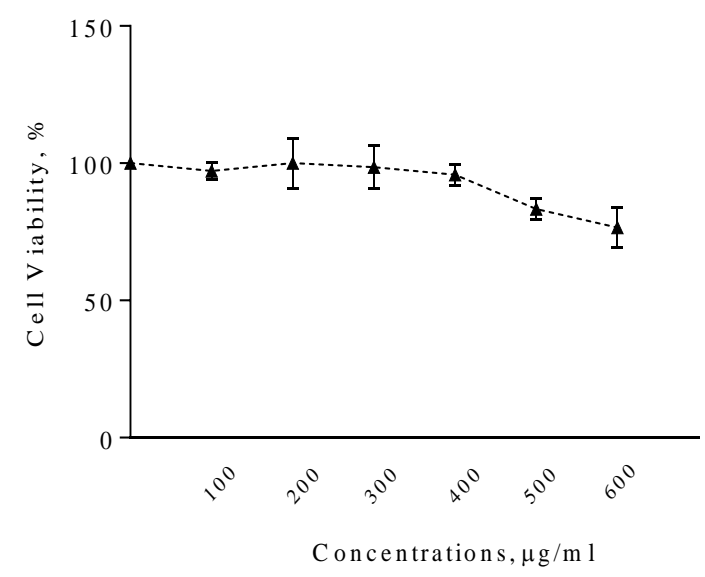

I Strobilanthes crispus

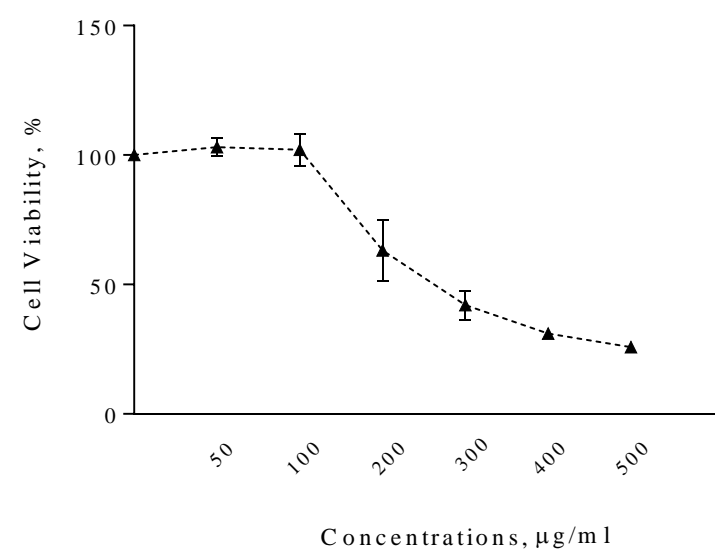

\section{$\mathbf{F}$}

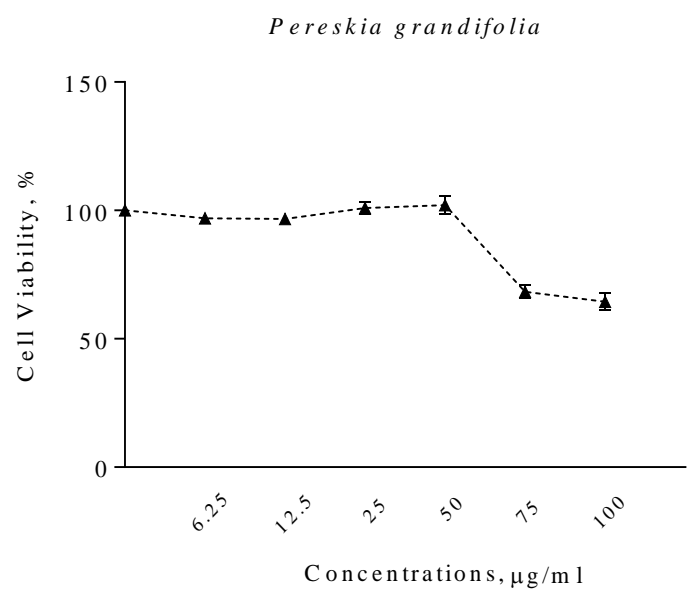

H

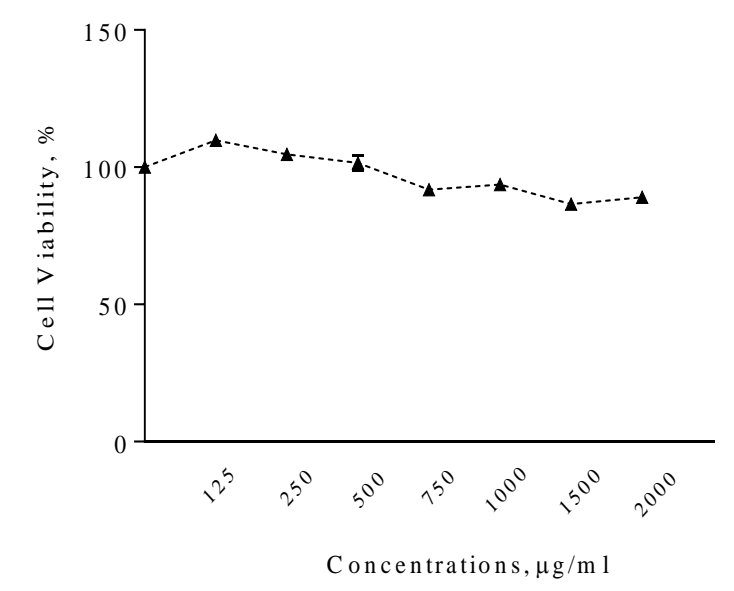

J

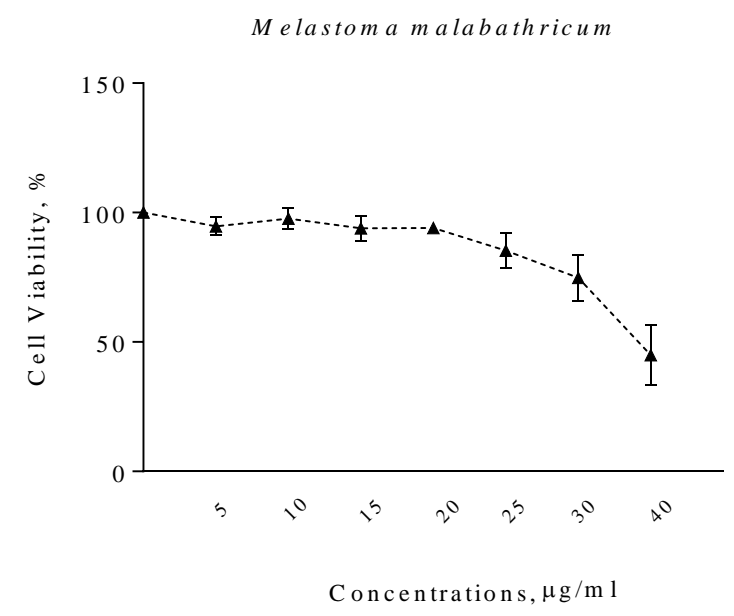

Figure 1. (continued). MTT assay for concentration-dependant of positive control drug and each plant extract towards cell viability under hypoxia. (E) Pereskia bleo (F) Pereskia grandifolia (G) Orthorsiphon aristatus (H) Clinicantus nutans (I) Strobilanthes crispus (J) Melastoma malabathricum. 
In hypoxia, $S$. cripus showed no prominent cytotoxicity under low plant extract concentrations of less than $100 \mu \mathrm{g} / \mathrm{ml}$ (Figure 1I). However, at concentrations higher than 200 $\mu \mathrm{g} / \mathrm{ml}$, the cells treated with plant extract exhibited evident decrease in cell viability. A similar curve pattern was noted for cells treated in normoxia at concentrations of $300 \mu \mathrm{g} / \mathrm{ml}$ (Supplementary Figure 1). In addition, cell viability was shown to be less than $15 \%$ when the cells were treated with $500 \mu \mathrm{g} / \mathrm{ml}$ of plant extract. In year 2005, Yaacob et al. demonstrated that $S$. cripus was able to induce almost $100 \%$ cell death when cells were treated with $100 \mu \mathrm{g} / \mathrm{ml}$ of plant extract under normal oxygen concentrations. In the current study, cells cultured both hypoxic and normoxic conditions showed minimal cell viability after treatment with $S$. cripus plant extract. $M$. malabathricum exhibited a gradual decrease in cell viability when the cells were treated with increasing concentrations of plant extracts. The same phenomena was observed for both hypoxic and normoxic incubated cells (Figure 1J). However, plant extract concentrations used to treat the cells were low, with a maximum concentration of $40 \mu \mathrm{g} / \mathrm{ml}$. Previous studies from Devehat et al. (2002) and Zakaria et al. (2011) reviewed this plant extract, stating that under normal oxygen concentration, the IC50 of the extract ranging from 13 to $>88 \mu \mathrm{g} / \mathrm{ml}$ for a panel of cancer cell lines. This suggested the cytotoxicity of this plant extract varied according to the cancer cells.

$\boldsymbol{H I F}$ activity. HIF is the master regulator for cells under low oxygen concentrations. HIF activity is the indication of cellular response for cells treated with various plant extracts under hypoxic conditions. To investigate HIF activity, a hypoxiadriven reporter assay (Kaluz et al., 2008) was performed in C3 samples treated with different concentrations of plant extracts. The signal intensity emitted from the assay is directly proportional to HIF activity. Positive values indicate inhibition of HIF activity while negative values showed HIF activation. The positive controls, cisplatin and bortezomib were shown to inhibit HIF activity tremendously (Figures $2 \mathrm{~A}$ and 2B). Both cisplatin and bortezomib are well known HIF inhibitors (Duyndam et al., 2007; Onnis et al., 2009).

For G. procumbens and H. sibthorpiodies, HIF activation was seen when the cells were treated with plant concentrations of 1000 and $750 \mu \mathrm{g} / \mathrm{ml}$ respectively (Figures $2 \mathrm{C}$ and $2 \mathrm{D}$ ). Whereas, for $P$. bleo, HIF activation was observed for all treatment concentrations (Figure 2E). P. grandifolia only showed HIF inhibition at $100 \mu \mathrm{g} / \mathrm{ml}$ (Figure 2F). The concentrations that displayed the highest HIF activation for the above mentioned four plants were $750,500,1500$, and $50 \mu \mathrm{g} / \mathrm{ml}$ respectively. For all four plants, cell viability exceeded $100 \%$ when the cells exhibited highest HIF activation levels. O. aristatus and $C$. nutans both displayed HIF activation for all concentrations of plant extracts (Figures $2 \mathrm{G}$ and 2H). HIF inhibition was observed when C3 cells were treated with concentrations of $S$. cripus exceeding $300 \mu \mathrm{g} / \mathrm{ml}$, and with $M$. malabathricum exceeding $1500 \mu \mathrm{g} / \mathrm{ml}$ (Figures 2I and 2J). HIF inhibition seen in $G$. procumbens, $H$. sibthorpiodies, $P$. grandifolia and $S$. cripus were due to low cell viability after treatment. Throughout the study, $C$. nutans was the only plant extract that displayed more than $100 \%$ of HIF activation alongside minimal cell cytotoxicity.

Adaptation and cellular responses towards hypoxic environments are complex. These adaptations play an important role in normal cellular physiology. HIF is the master regulatory upon all the hypoxia cellular responses (Semenza, 2011). This regulatory is thought to be responsible for the occurrence of many diseases. The use of plant extract is considered an optional alternative for drug discovery research targeted at curing these diseases. Therefore, the screening of different plant extracts dosages in this study helps in understanding the effect of the extracts towards cells viability and HIF activity under hypoxia. To conclude, evidence of more than 100\% HIF activation and minimal cell cytotoxicity towards cells when treated with $C$. nutans makes it as a primary candidate for HIF activation-related drug screening. Potent HIF activators exhibit low toxicity and can be identified by showing activation of HIF activity at a transcriptional level (Nagle \& Zhou, 2006). 
B

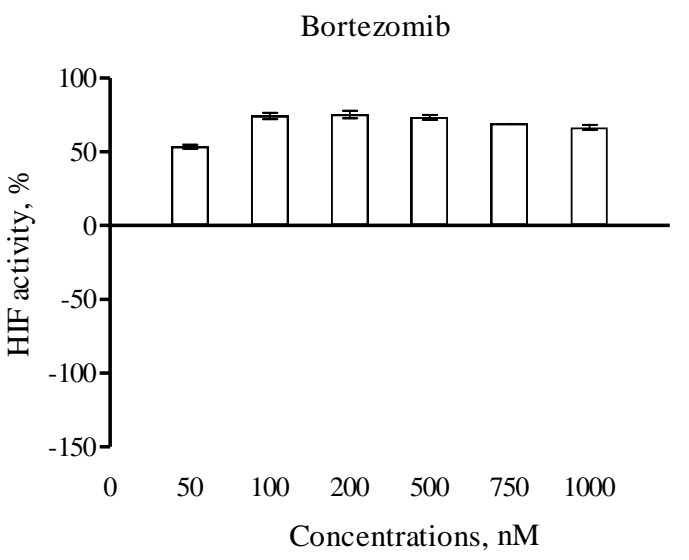

D

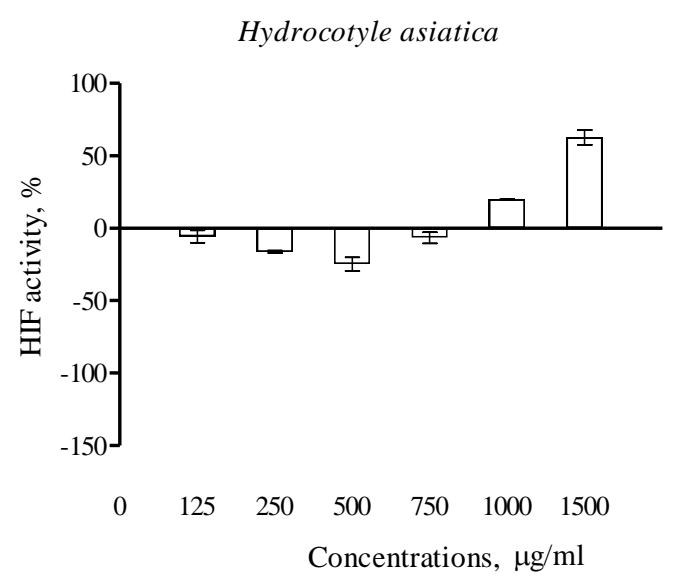

$\mathbf{F}$

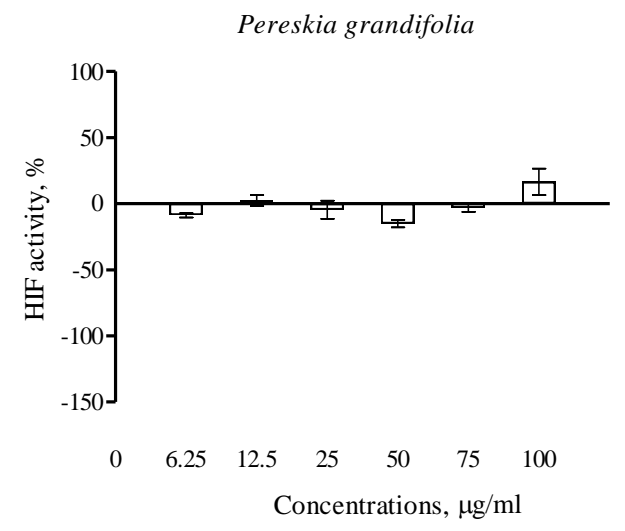

Figure 2. HIF activity shown by $\mathrm{C} 3$ cells when treated with plant extracts of various concentration and incubated under hypoxia. (A) Cisplatin (B) Bortezomib (C) Gynura procumbens (D) Hydrocotyle sibthorpiodies (E) Pereskia bleo (F) Pereskia grandifolia. 
G

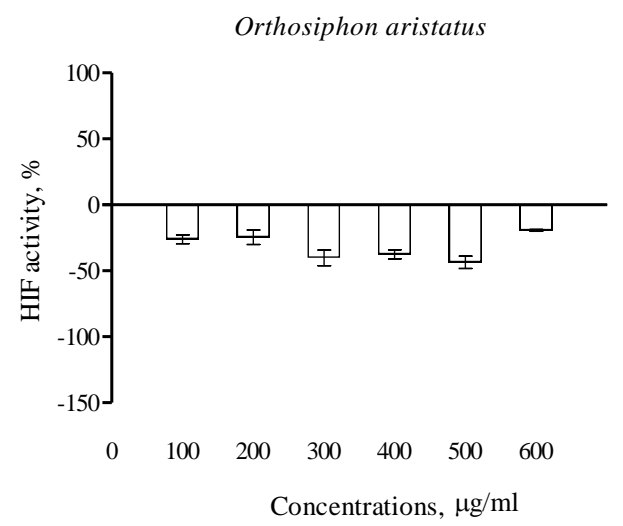

I

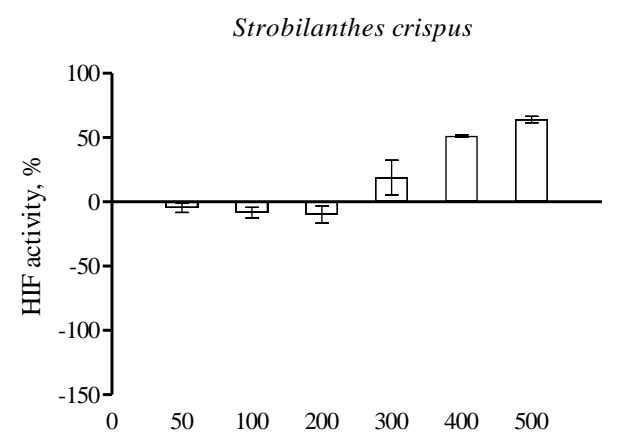

Concentrations, $\mu \mathrm{g} / \mathrm{ml}$
H

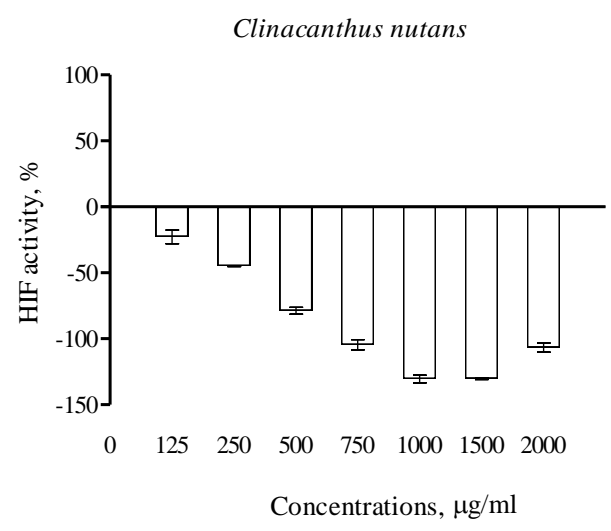

J

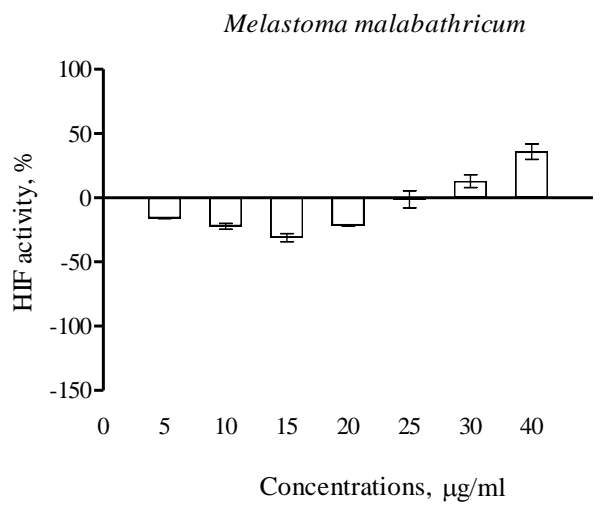

Figure 2. (continued). HIF activity shown by $\mathrm{C} 3$ cells when treated with plant extracts of various concentration and incubated under hypoxia. (G) Orthorsiphon aristatus (H) Clinicantus nutans (I) Strobilanthes crispus (J) Melastoma malabatbricum.

\section{ACKNOWLEDGMENTS}

This work was partially supported by the MyBrain15 from the Malaysia government and Graduate Research Fellowship, Universiti Putra Malaysia.

\section{REFERENCES}

Arullappan, S., Rajamanickam, P., Thevar, N., \& Kodimani, C. C. 2014. In vitro screening of cytotoxic, antimicrobial and antioxidant activities of Clinacanthus nutans (Acanthaceae) leaf extracts. Tropical Journal of Pharmacentical Research 13(9): 1455-1461.
Befani, C. D., Vlachostergios, P. J., Hatzidaki, E., Patrikidou, A., Bonanou, S., Simos, G. Papandreou, C. N. \& Liakos, P. 2012. Bortezomib represses HIF- $1 \alpha$ protein expression and nuclear accumulation by inhibiting both $\mathrm{PI} 3 \mathrm{~K} / \mathrm{Akt} / \mathrm{TOR}$ and MAPK pathways in prostate cancer cells. Journal of Molecular Medicine 90(1): 45-54.

Birbrair, A., Zhang, T., Wang, Z. M., Messi, M. L., Mintz, A., \& Delbono, O. 2015. Pericytes at the intersection between tissue regeneration and pathology. Clinical Science 128(2): 8193.

Duyndam, M. C., van Berkel, M. P., Dorsman, J. C., Rockx, D. A., Pinedo, H. M., \& Boven, E. 2007. Cisplatin and doxorubicin repress vascular endothelial growth factor expression and differentially down-regulate hypoxiainducible factor I activity in human ovarian cancer cells. Biochemical Pharmacology 74(2): 191-201.

Gunaratnam, L., \& Bonventre, J. V. 2009. HIF in kidney disease and development. Journal of the American Society of Nephrology 20(9): 1877-1887.

Harris, A. L. 2002. Hypoxia-a key regulatory factor in tumour growth. Nature Reviews Cancer 2(1): 38. 
Kaluz, S., Kaluzová, M., \& Stanbridge, E. J. 2008. Regulation of gene expression by hypoxia: integration of the HIFtransduced hypoxic signal at the hypoxia-responsive element. Clinica Cbimica Acta 395(1-2): 6-13.

Katiyar, C., Gupta, A., Kanjilal, S., \& Katiyar, S. 2012. Drug discovery from plant sources: An integrated approach. Ayu 33(1): 10.

Liew, S. Y., Stanbridge, E. J., Yusoff, K., \& Shafee, N. 2012. Hypoxia affects cellular responses to plant extracts. Journal of Ethnopharmacology 144(2): 453-456.

Lohézic-Le Dévéhat, F., Bakhtiar, A., Bezivin, C., Amoros, M., \& Boustie, J. 2002. Antiviral and cytotoxic activities of some Indonesian plants. Fitoterapia 73(5): 400-405.

Mabjeesh, N. J., \& Amir, S. 2007. Hypoxia-inducible factor (HIF) in human tumorigenesis. Histology and Histopathology 22(4/6): 559.

Mace, K. A., Yu, D. H., Paydar, K. Z., Boudreau, N., \& Young, D. M. 2007. Sustained expression of HIF-1 $\alpha$ in the diabetic environment promotes angiogenesis and cutaneous wound repair. Wound Repair and Regeneration 15(5): 636-645.

Nagle, D. G., \& Zhou, Y. D. 2006. Natural product-derived small molecule activators of hypoxia-inducible factor-1 (HIF1). Current Pharmaceutical Design 12(21): 2673-2688.

Nurestri, A. S., Sim, K. S., \& Norhanom, A. W. 2009. Phytochemical and cytotoxic investigations of Pereskia grandifolia Haw.(Cactaceae) leaves. Journal of Biological Sciences 9(5): 488-493.

Onnis, B., Rapisarda, A., \& Melillo, G. 2009. Development of HIF-1 inhibitors for cancer therapy. Journal of Cellular and Molecular Medicine 13(9a): 2780-2786.

Pan, S. Y., Zhou, S. F., Gao, S. H., Yu, Z. L., Zhang, S. F., Tang, M. K., .Sun, J. N., Ma, D. L., Han, Y. F., Fong, W. F. \& Ko, K. M. 2013. New perspectives on how to discover drugs from herbal medicines: CAM's outstanding contribution to modern therapeutics. Evidence-Based Complementary and Alternative Medicine 2013.

Paul, J., Gnanam, R., M Jayadeepa, R., \& Arul, L. 2013. Anti cancer activity on Graviola, an exciting medicinal plant extract vs various cancer cell lines and a detailed computational study on its potent anti-cancerous leads. Current Topics in Medicinal Chemistry 13(14): 1666-1673.

Semenza, G. L. 2011. Hypoxia. Cross talk between oxygen sensing and the cell cycle machinery. American Journal of PhysiologyCell Physiology 301(3): C550.

Shafee, N., Stanbridge, E. J., Yusoff, K. \& Liew, S.Y. 2015. U.S. Patent Application No. 14/415,064.

Sharif, K. M., Rahman, M. M., Zaidul, I. S. M., Jannatul, A., Akanda, M. J. H., Mohamed, A., \& Shamsudin, S. H. 2013. Pharmacological relevance of primitive leafy cactuses Pereskia. Research Journal of Biotechnology 8: 134-142.

Somboonwong, J., Kankaisre, M., Tantisira, B., \& Tantisira, M. H. 2012. Wound healing activities of different extracts of Centella asiatica in incision and burn wound models: an experimental animal study. BMC Complementary and Alternative medicine 12(1): 103.

Stroka, D. M., Burkhardt, T., Desbaillets, I., Wenger, R. H., Neil, D. A., Bauer, C., Gasmann, M. \& Candinas, D. 2001. HIF1 is expressed in normoxic tissue and displays an organspecific regulation under systemic hypoxia. The FASEB Journal 15(13): 2445-2453.

Tan, M. L., Sulaiman, S. F., Najimuddin, N., Samian, M. R., \& Muhammad, T. T. 2005. Methanolic extract of Pereskia bleo (Kunth) DC.(Cactaceae) induces apoptosis in breast carcinoma, T47-D cell line. Journal of Ethnopharmacology 96(12): $287-294$.

Vijayakumar, S., \& Ganesan, S. 2012. In vitro cytotoxicity assay on gold nanoparticles with different stabilizing agents. Journal of Nanomaterials 14.
Vijayan, C. H. I. T. H. R. A., Adersh, M., Reji, S. R., \& Nair, G. M. 2013. Screening biological activities of Orthosiphon aristatus. International Journal of Pharmacy and Pharmaceutical Sciences 5(4): 594-600.

Yaacob, N. S., Yankuzo, H. M., Devaraj, S., Wong, J. K. M., \& Lai, C. S. 2015. Anti-tumor action, clinical biochemistry profile and phytochemical constituents of a pharmacologically active fraction of S. crispus in NMU-induced rat mammary tumour model. PLOS One 10(5): e0126426.

Yong, Y. K., Tan, J. J., Teh, S. S., Mah, S. H., Ee, G. C. L., Chiong, H. S., \& Ahmad, Z. 2013. Clinacantbus nutans extracts are antioxidant with antiproliferative effect on cultured human cancer cell lines. Evidence-Based Complementary and Alternative Medicine 2013.

Zakaria, Z. A., Rofiee, M. S., Mohamed, A. M., Teh, L. K., \& Salleh, M. Z. 2011. In vitro antiproliferative and antioxidant activities and total phenolic contents of the extracts of Melastoma malabathricum leaves. Journal of Acupuncture and Meridian Studies 4(4): 248-256.

Ziello, J. E., Jovin, I. S., \& Huang, Y. 2007. Hypoxia-inducible factor (HIF)-1 regulatory pathway and its potential for therapeutic intervention in malignancy and ischemia. The Yale Journal of Biology and Medicine 80(2): 51. 